\title{
A COMPARATIVE STUDY ON CRITICAL QUESTIONING SKILLS OF BILINGUAL ADULTS IN L1 AND L2
}

\author{
Feryal Cubukcu* \\ Dokuz Eylul University \\ Vesile Yildız Demirtas** \\ Dokuz Eylul University
}

This study reports the comparison of the levels of the critical questioning skills of English preservice language teachers. By examining their questions in relation with four stories, this research employs Bloom's critical questioning paradigm to explore whether bilinguals have the same level of critical questioning in L1 and L2. The results showcase that bilinguals do not have the same frequency of questioning skills, which has implications for teacher educators as the preservice language teachers' inquiry skills show diversity and variation. The relationship between bilingualism and critical questioning is mediated by the level of language proficiency, which helps to explain some of the inconsistent findings reported by the past research.

Keywords: bilingualism, critical questioning, language

\section{INTRODUCTION}

The research on cognitive consequences of bilingualism has a long history that dates back to the beginning of the $20^{\text {th }}$ century. It has always been a controversial topic among the linguists and applied linguists. The effects of bilingualism on cognitive characteristics and questioning skills have only recently become a topic of research. From its beginnings, bilingual research has been concerned with the domains of intelligence and linguistic and metalinguistic performance. This trend reflects an intuitive understanding that bilingualism must affect linguistic performance. One of the earliest studies showed that bilingual kids have mental confusion compared to monolingual kids (Saer, 1923). The later studies maintain that there were no differences between monolingual and bilingual children in non-verbal intelligence (Peal \& Lambert, 1962; Bialystok, 1986, 1993, 2001). This observation set the stage for finding cognitive benefits of bilingualism or at least for distancing from the early notion of pervasive bilingual cognitive disadvantages. Some studies have shown that the experience of speaking

\footnotetext{
* cubukcu.feryal@gmail.com

** vesile.yildiz@deu.edu.tr
} 
two languages on a daily basis has consequences for the way in which higher cognitive processes operate and results in more precocious development of attentional abilities (Bialystok \& Martin, 2004; Mezzacappa, 2004; Costa, Hernández, \& Sebastián-Gallés, 2008). Furthermore, there has been an inconsistent profile of findings in which bilingualism facilitates, hinders, or does not make any difference to the development of phonological awareness skills in bilinguals.

Barac et al. (2014) summarize the present knowledge about cognitive development of bilinguals in the following way:

First, across studies, non-verbal executive control skills and theory of mind abilities were changed by the experience of speaking or being exposed to two languages, and typically bilingual children showed more advanced skills than their monolingual peers. Second, the bilingual advantage was not found for all executive control skills (see response inhibition, or delay of gratification, for instance, where bilinguals perform similarly to monolinguals; Carlson \& Meltzoff, 2008; MartinRhee \& Bialystok, 2008). The existing evidence suggests that tasks need to carry relatively high executive demands to distinguish between monolinguals and bilinguals. In addition, the bilingual advantage is not found only on tasks that have inhibitory demands, as initially proposed, but extends to switching and cognitive flexibility among others (Barac \& Bialystok, 2011; Bialystok, 2010). Working memory is one executive control process that has been relatively less studied and thus the evidence is less clear. The existing findings, however, suggest that bilinguals outperform monolinguals when there are increases in the executive demands of the working memory tasks (Morales et al., 2013). Third, differences in executive control were found very early on, in the first year of life, indicating that being exposed to two languages and not necessarily speaking two languages, has consequences for cognitive processing (Kovacs \& Mehler, 2009). Fourth, bilingual children showed different pattern of brain responses to processing linguistic stimuli, adding to the extensive literature demonstrating bilingualism effects at the behavioral level (Conboy \& Mills, 2006). (Barac et al., 2014: 711)

Although similar reviews to that of Barac et. al. (2014) and meta-analyses already exist in the literature (Adesope, Lavin, Thompson \& Ungerleider, 2010; Barac \& Bialystok, 2011; Branum-Martin, Tao, Garnaat, Bunta, \& Francis, 2012), the present study is unique in its focus on pre-service English language teachers, whose comprehensive range of questioning processes is reviewed. Given that dual language exposure and bilingualism are relatively common experiences for language teachers, identifying the abilities that are affected by bilingualism has important implications for the theoretical 
understanding of cognitive architecture and the plasticity of bilingualism, and whether their questioning skills are close to each other in both languages.

The purpose of the study is to examine whether bilingual pre-service English language teachers have similar questioning skills in both their languages - Turkish as L1 and English as L2.

\section{METHODOLOGY}

\subsection{Participants}

60 pre-service English language teachers participated in the study on a voluntary basis. They passed two national tests on language proficiency designed by the Higher Council of Education, which qualifies them to work at the language teaching department. When they entered the programme, their proficiency level was C1. When they asked questions about the stories, they were in their fourth/last year of the programme and were going to graduate in 2 months. Their age range was between 22 and 23. Out of 60 participants, 32 were female and 28 were male. Pre-service language teachers were considered as bilinguals as they had been studying English since the second grade of primary school (since they were eight years old). All the participants signed the informed consent forms.

\subsection{Stories}

The pre-service language teachers were given the assignment to read four stories: two written in Turkish and two in English. They were asked to read them and list down as many questions as possible. The English stories and Turkish stories were given on consecutive weeks. The selection criteria for these stories were the following:

- In each language, one story is abstract (Rose and Pelin have a tendency to forget things) and the other concrete (Emre's fondness for reading and the crow fable).

- The same story on forgetfulness is given in both languages to see whether there are similarities between L1 and L2 questioning skills.

- The crow story is selected as it is a fable the participants are very familiar with.

English Story 1

When Rose entered the class, all students started to stare at her because that day there was some oddness about her. All sorts of threads were hanging with the slips of paper attached. There was something scribbled on these slips. Her friends began to inquire "what are these slips for?". Rose calmly sat down and thought that she had not forgotten anything as she had written everything she might have forgotten on these slips of paper. 
On the slips, the information was on what her name was, who her parents were, where she played the day before, that in winters coats were worn, in summers light jackets, that Sunday was after Saturday and before Monday, that she had to blink her eyes while looking at the sun, and that she should thank when she was given something nice.

\section{English Story 2}

Fox once sees a Crow fly off with a piece of cheese in its beak and settle on a branch of a tree. "That's for me" said Fox, and he walks up to the foot of the tree. "Good day" he cries. "How well you look today: how glossy your feathers are; how bright your eyes are. Let me hear one song from you that I may greet you as the Queen of Birds."

The Crow lifts up her head and begins to sing her best, but the moment she opens her mouth the piece of cheese falls to the ground, only to be snapped up by Fox.

\section{Turkish Story 1}

This story deals with a young boy named Emre, who is tired of being mocked in the class because he loves reading, whereas his friends prefer to play videogames. He justifies his reading by claiming everybody should be entitled to do what they are happy with and he believes reading books brings him joy and happiness.

\section{Turkish Story 2}

The second story is the Turkish adaptation of the English story of Rose. The story's protagonist is Pelin, who walks around with the slips of paper not to forget things.

\subsection{Method of Analysis}

The questions were analysed through the following taxonomy based on critical questioning skills. Barden (1995: 423) defined higher order questions as "those that require more than simple recall to produce an answer" and lower order questions as "those that require responses either recalled directly from memory or cited explicitly in text". Lower level thinking questions were constructed using the first three levels of Bloom's Taxonomy (remembering, understanding, and applying). The higher order thinking questions were based on the strategies from Frank E. Williams's (1972) Total Creativity Program for Individualizing and Humanizing the Learning Process. 
Table 1. Lower level and higher order questioning techniques (Walsh \& Kemp, 2013: 114)

\begin{tabular}{|c|c|c|}
\hline \multirow[t]{3}{*}{$\begin{array}{l}\text { Lower } \\
\text { level }\end{array}$} & $\begin{array}{l}\text { Remembering - Exhibit memory of previously } \\
\text { learned materials by recalling facts, terms, basic } \\
\text { concepts and answers }\end{array}$ & $\begin{array}{l}\text { Why didn't Cinderella go to the } \\
\text { ball? }\end{array}$ \\
\hline & $\begin{array}{l}\text { Understanding - Demonstrate understanding } \\
\text { of facts and ideas by organizing, comparing, } \\
\text { translating, interpreting, giving descriptions, and } \\
\text { stating main ideas }\end{array}$ & $\begin{array}{l}\text { How did Cinderella manage to } \\
\text { get to the ball in the end? }\end{array}$ \\
\hline & $\begin{array}{l}\text { Applying - Solve problems, apply to new } \\
\text { situations by applying acquired knowledge, facts, } \\
\text { techniques and rules in a different way }\end{array}$ & $\begin{array}{l}\text { Why did the Prince fall in love } \\
\text { with Cinderella? }\end{array}$ \\
\hline \multirow[t]{5}{*}{$\begin{array}{l}\text { Higher } \\
\text { order }\end{array}$} & $\begin{array}{l}\text { Analogy - Situations of likeness; similarities } \\
\text { between two things }\end{array}$ & $\begin{array}{l}\text { How is Cinderella like a } \\
\text { butterfly? }\end{array}$ \\
\hline & $\begin{array}{l}\text { Provocative Question - Inquiry to bring } \\
\text { forth meaning, summons to discovering new } \\
\text { knowledge }\end{array}$ & $\begin{array}{l}\text { What would happen if we all had } \\
\text { a fairy Godmother? }\end{array}$ \\
\hline & $\begin{array}{l}\text { Paradox - A situation opposed to common sense, } \\
\text { self-contradictory statement, or observation }\end{array}$ & $\begin{array}{l}\text { Can ugly people be beautiful? } \\
\text { Why? Why not? }\end{array}$ \\
\hline & $\begin{array}{l}\text { Attribute Listing - Inherent properties, ascribing } \\
\text { qualities }\end{array}$ & $\begin{array}{l}\text { What are the important qualities } \\
\text { of a fairy Godmother? }\end{array}$ \\
\hline & $\begin{array}{l}\text { Tolerance for Ambiguity - Pose open-ended } \\
\text { situations which do not force closure }\end{array}$ & $\begin{array}{l}\text { How might the story have been } \\
\text { different if Cinderella had not lost } \\
\text { her slipper? }\end{array}$ \\
\hline
\end{tabular}

The researchers categorized the questions that participants wrote using the taxonomy of lower level and higher order questioning techniques (see Table 1) first separately. The inter-rater reliability was found to be .90 .

\subsection{Data Results}

The results of the analysis revealed that pre-service language teachers had higher rates for the Turkish stories in terms of the total number of questions (493 versus 392). Table 2 shows the scores for the Turkish stories. Their lower questioning skills outnumber higher questioning skills, especially in Pelin's story $(68.7 \%)$. It is counterintuitive that, although both stories are Turkish, the second story about Pelin's habit of forgetting things has more irrelevant questions $(14.15 \%$ versus $4.98 \%)$ 
Table 2.Turkish Stories

\begin{tabular}{|c|c|c|c|c|}
\hline \multirow{2}{*}{ Items } & \multicolumn{2}{|c|}{ Emre's love for reading } & \multicolumn{2}{|c|}{ Pelin's forgetting } \\
\hline & $\mathrm{n}$ & $\mathrm{f}$ & $\mathrm{n}$ & $\mathrm{f}$ \\
\hline Knowledge & 58 & 20.64 & 32 & 15.09 \\
\hline Understanding & 39 & 13.87 & 68 & 32.07 \\
\hline Application & 31 & 11.03 & 46 & 21.69 \\
\hline Attribute listing & 61 & 21.7 & 10 & 4.71 \\
\hline Paradox & 50 & 17.79 & 13 & 6.13 \\
\hline Provocative questioning & 24 & 8.54 & 4 & 1.88 \\
\hline Ambiguity tolerance & 4 & 1.42 & 9 & 4.24 \\
\hline Irrelevant & 14 & 4.98 & 30 & 14.15 \\
\hline Total & 281 & 100 & 212 & 100 \\
\hline
\end{tabular}

In the case of English stories (Table 3), pre-service language teachers had a lot of grammatical mistakes, so their questions were discarded and the percentages for the eliminated questions due to ungrammaticality reach $28.78 \%$ and $31.08 \%$ respectively.

Table 3. English stories

\begin{tabular}{|c|c|c|c|c|}
\hline \multirow{2}{*}{ Items } & \multicolumn{2}{|c|}{ Forgetful student } & \multicolumn{2}{|c|}{ Crow and fox } \\
\hline & $\mathrm{n}$ & f & $\mathrm{n}$ & $\mathrm{f}$ \\
\hline Knowledge & 36 & 18.18 & 3 & 1.55 \\
\hline Understanding & 22 & 11.11 & 2 & 1.03 \\
\hline Application & 5 & 2.52 & 11 & 5.69 \\
\hline Attribute listing & 36 & 18.18 & 31 & 16.06 \\
\hline Paradox & 2 & 1 & 7 & 3.62 \\
\hline Provocative questioning & 33 & 16.66 & 75 & 38.86 \\
\hline Ambiguity tolerance & 7 & 3.53 & 5 & 2.59 \\
\hline Ungrammatical expressions & 57 & 28.78 & 60 & 31.08 \\
\hline Total & 198 & 100 & 194 & 100 \\
\hline
\end{tabular}

The contrastive table (Table 4) highlights the main discrepancies of the questioning between Turkish and English stories. Pre-service teachers excel at asking lower level thinking questions in L1 (55.5\%). Although they do not have high scores at asking higher order questions (49\%), they are especially very good at asking provocative questions (27.5\%) in L2, e.g.

1 . Why is cheese the chosen food in the fable?

2. Would you have empathy for the crow or the fox as both are hungry?

3. What would you do if you had Rose's forgetfulness?

4. How would the world turn out to be if everybody were happy? 
Higher thinking skills of the participants show almost similar scores in the categories of "attribute listing" and "ambiguity tolerance". They outperform at "provocative questioning" and have lower scores in "paradox" in L2. However, the eliminated questions are more frequent in L2 than L1 due to the participants' lack of syntactical or lexical slips, e.g.

1. *Is flattered human weakness?

2. *Is it hard to figure that they have reason when we flatter?

Table 4. Comparison

\begin{tabular}{|c|c|c|c|c|}
\hline & $\operatorname{Tr}$ & $\operatorname{Tr}$ & Eng & Eng \\
\hline & $\mathrm{n}$ & $f$ & $\mathrm{n}$ & $\mathrm{f}$ \\
\hline Knowledge & 90 & 18.25 & 39 & 9.94 \\
\hline Understanding & 107 & 21.7 & 24 & 6.12 \\
\hline Application & 77 & 15.6 & 16 & 4.08 \\
\hline Attribute listing & 71 & 14.4 & 67 & 17.09 \\
\hline Paradox & 63 & 12.77 & 9 & 2.29 \\
\hline Provocative questioning & 28 & 5.67 & 108 & 27.55 \\
\hline Ambiguity tolerance & 13 & 2.63 & 12 & 3.06 \\
\hline Irrelevant & 44 & 8.92 & 117 & 29.84 \\
\hline Total & 493 & 100 & 392 & 100 \\
\hline
\end{tabular}

\section{DISCUSSION AND CONCLUSION}

Bilingualism is defined as the existence of two different languages within the speech repertoire of either an individual or a society. There are two types of bilingualism: individual, which is acquired in the family, and societal, which is used to refer to any kind of bilingualism at a level of social organization beyond the individual or nuclear family, which might mean that almost every country and region of the world has some degree of societal bilingualism (Hoffman, 2014). In this study the societal bilingualism of the Turkish teachers of English were studied. There has been a lot of research on the effects of bilingualism on individuals, which give contradictory results. On the one hand, there are studies (Arsenian, 1937; Bruck et al., 1974; Hill, 1936; Kittell, 1959; Pintner \& Arsenian, 1937) which claim that there are no differences. On the other hand, some studies maintain that bilinguals outperform monolinguals (Bain, 1974; Ben-Zeev, 1977; Bialystok, 1986, 1993, 2001; Cummins \& Gulutsan, 1974; Darcy,1946, 1953; Diaz, 1983; Feldman \& Shen, 1971; Ianco-Worrall, 1972; Kovacs \& Mehler, 2009; Lambert \& MacNamara, 1969; Peal \& Lambert, 1962; Stark, 1940). However, some studies show that monolinguals excel at language skills (Lewis, 1959; Torrence et al., 1970). 
The results of this study, in which the English pre-service language teachers' critical questioning skills in L1 and L2 were compared and contrasted, have shown that bilinguals overall have the same critical questioning development in both languages. In Turkish they are better at lower order questioning (55.5\%), whereas in English higher thinking skills reach $49 \%$. However, when it comes to the type of the story, it is obvious that they are better at concrete stories in both languages (49\% in Turkish and $60.5 \%$ in English). Since they study at the Department of English Language Teaching, they read English books and use English as the language of instruction, so they are highly proficient, despite the grammatical errors they display. It is counterintuitive, however, that nearly $30 \%$ of the answers in English are grammatically incorrect. Therefore, they were eliminated, which leads to the same idea as the one supported by Cummins $(1978,1979)$, who explains the interdependence of language and cognitive ability in bilinguals through the 'threshold hypothesis'. The idea is that bilinguals need to achieve certain levels of proficiency in both languages in order to avoid negative developmental outcomes and show cognitive benefits. Therefore, it is the attainment of adequate language levels of proficiency in both languages that paves the way for the outperformance of the bilinguals. It is also in line with Cummins' study, as he elaborates on the idea that the relationship between bilingualism and cognitive/academic outcomes is mediated by the level of language proficiency. This helps to explain some of the inconsistent findings reported by past research. Consequently, the results could be attributed to two facts, mainly the pre-service teachers' lack of high proficiency English skills and secondly, the lack of transfer between two languages, showcasing that there are two different systems for two different languages.

\section{REFERENCES}

Adesope, O. O., Lavin, T., Thompson, T. and Ungerleider, C. (2010) Systematic review and meta-analysis on the cognitive benefits of bilingualism. Review of Educational Research 80 (2), 207245.

Arsenian, S. (1937) Bilingualism and mental development. New York, NY: College Press.

Bain, B.(1974) Bilingualism and cognition: Toward a general theory. In Carey, S. T. (ed) Bilingualism, biculturalism, and education. Edmonton, Canada: University of Alberta, 119-128.

Barac, R. and Bialystok, E. (2011) Cognitive development of bilingual children. Language Teaching, $44,36-54$.

Barac, R. and Bialystok, E. (2012) Bilingual effects on development: Role of language, cultural background, and education. Child Development 83 (2), 413-422.

Barac, R., Bialystok, E.,Castro, D. and Sanchez, M. (2014) The cognitive development of young dual language learners: A critical review. Early Childhood Research Quarterly 29 (4), 699-714.

Barden, L. M. (1995) Effective questioning and the ever-elusive higher-order question. The American Biology Teacher 57 (7), 423-426.

Ben-Zeev, S. (1977) The influence of bilingualism on cognitive strategy and cognitive development. Child Development 48, 1009-1018. 
Bialystok, E. (1986) Factors in the growth of linguistic awareness. Child Development 57, 498-510.

Bialystok, E. (1993) Metalinguistic awareness: The development of children's representations of language. In Pratt, C. A. and Garton, E. (eds) The development and use of representation in children. London, UK: Wiley, 211-233.

Bialystok, E. (2001) Bilingualism in development: Language, literacy, and cognition. New York, NY: Cambridge University Press.

Bialystok, E. (2009) Claiming evidence from non-evidence: A reply to Morton and Harper. Developmental Science 12 (4), 499-501.

Bialystok, E. (2010) Global-local and trail-making tasks by monolingual and bilingual children: Beyond inhibition. Developmental Psychology 46 (1), 93-105.

Bialystok, E. and Martin, M. M. (2004) Attention and inhibition in bilingual children: Evidence from the dimensional change card sort task. Developmental Science 7 (3), 325-339.

Branum-Martin, L., Tao, S., Garnaat, S., Bunta, F. and Francis, D. (2012) Meta-analysis of bilingual phonological awareness: Language, age, and psycholinguistic grain size. Journal of Educational Psychology 104 (4), 932-944.

Bruck, M., Lambert, W. E. and Tucker, G. R. (1974) Bilingual schooling through the elementary grades: the St. Lambert project at grade seven. Language Learning 24 (2), 183-204.

Costa, A., Hernández, M. and Sebastián-Gallés, N. (2008) Bilingualism aids conflict resolution: Evidence from the ANT task. Cognition 106 (1), 59-86.

Cummins, J. and Gulutsan, M.(1974) Some effects of bilingualism on cognitive functioning. In Carey, S. T. (ed) Bilingualism, biculturalism, and education. Edmonton, Canada: University of Alberta, 129-136.

Cummins, J. (1978) Bilingualism and the development of metalinguistic awareness. Journal of Cross-Cultural Psychology 9 (2), 131-149.

Cummins, J.(1979) Linguistic interdependence and the educational development of bilingual children. Review of Educational Research 49 (2), 222-251.

Darcy, N. T. (1946) The effect of bilingualism upon the measurement of the intelligence of children of preschool age. The Journal of Educational Psychology 37 (1), 21-44.

Darcy, N. T. (1953) A review of the literature on the effects of bilingualism upon the measurement of intelligence. Journal of Genetic Psychology 82 (1), 21-57.

Diaz, R. M. (1983) Thought and two languages: the impact of bilingualism on cognitive development. Review of Research in Education 10 (1), 23-54.

Feldman, C. and Shen, M. (1971) Some language-related cognitive advantages of bilingual fiveyear-olds. Journal of Genetic Psychology 118 (2), 235-244.

Hill, H. S. (1936) The effect of bilingualism on the measured intelligence of elementary school children of Italian parentage. The Journal of Experimental Education 5 (1), 75-79.

Hoffman, C. (2014) Introduction to bilingualism. London: Taylor-Francis

Ianco-Worrall, A. (1972) Bilingualism and cognitive development. Child Development 43, 1390-1400.

Kittell, J. E. (1959) Bilingualism and language: non-language intelligence scores of third grade children. Journal of Educational Research 52 (7), 263-268.

Kovacs, Á. M. and Mehler, J. (2009) Cognitive gains in 7-month-old bilingual infants. Proceedings of the National Academy of Sciences 106 (16), 6556-6560.

Lambert, W. E. and MacNamara, J. (1969) Some cognitive consequences of following a first-grade curriculum in a second language. Journal of Educational Psychology 60 (2), 86-96.

Lewis, D. G. (1959) Bilingualism and non-verbal intelligence: A further study of test results. British Journal of Educational Psychology 29 (1), 17-22.

Mezzacappa, E. (2004) Alerting, orienting, and executive attention: Developmental properties and socio-demographic correlates in an epidemiological sample of young, urban children. Child Development 75 (5), 1373-1386.

Peal, E. and Lambert, W. E. (1962) The relation of bilingualism to intelligence. Psychological Monographs $76,1-23$.

Pintner, R. and Arsenian, S.(1937) The relation of bilingualism to verbal intelligence and school adjustment. Journal of Educational Research 31 (4), 255-263. 
Saer, D. J. (1923) The effect of bilingualism on intelligence. The British Journal of Psychology 14 (1), 25-38.

Stark, W. A. (1940) The effect of bilingualism on general intelligence: An investigation carried out in certain Dublin primary schools. British Journal of Educational Psychology 10 (1), 78-79.

Torrance, E. P., Gowan, J. C.,Wu, J. M. and Aliotti, N. C. (1970) Creative functioning of monolingual and bilingual children in Singapore. Journal of Educational Psychology 61 (1), 72-75.

Walsh, R. and Kemp, C. (2013) Evaluating Interventions for Young Gifted Children Using Single-Subject Methodology A Preliminary Study. Gifted Child Quarterly 57 (2), 110-120.

Williams, F. E. (1972) Total creativity program for individualizing and humanizing the learning process. Englewood Cliffs, NJ: Educational Technology.

\section{USPOREDNO ISTRAŽIVANJE DVOJEZIČNIH ODRASLIH OSOBA U VJEŠTINI POSTAVLJANJA PITANJA ZA POTICANJE KRITIČKOG RAZMIŚLJANJA NA PRVOM I DRUGOM JEZIKU}

U ovom se istraživanju prikazuju rezultati usporedbe budućih nastavnika engleskog jezika s obzirom na razinu njihove vještine postavljanja pitanja za poticanje kritičkog razmišljanja. Kako bi se ispitalo posjeduju li dvojezične osobe istu razinu vještine postavljanja kritičkih pitanja u prvom i drugom jeziku, analiza pitanja postavljenih za četiri različite priče temeljila se na Bloomovoj taksonomiji kritičkog ispitivanja. Rezultati pokazuju da učestalost s kojom dvojezične osobe postavljaju pitanja za poticanje kritičkog razmišljanja nije ista, tj. utvrđene su raznolikost i odstupanja u navedenoj vještini budućih nastavnika, što je relevantno za one koji ih obrazuju. Odnos dvojezičnosti i postavljanja pitanja za kritičko razmišljanje posredovano je razinom jezičnog umijeća, što pomaže objasniti neke nedosljednosti u nalazima prethodnih istraživanja.

Ključne riječi: dvojezičnost, kritičko ispitivanje, jezik 